\title{
Hygiene related practices amongst school children living in a slum of Pune
}

\author{
Sudhanshu Ashok Mahajan ${ }^{1 *}$, Jayashree Sachin Gothankar ${ }^{2}$, Rupesh Balasaheb Deshmukh ${ }^{3}$ \\ ${ }^{\mathbf{1}}$ Assistant Professor, ${ }^{2}$ Professor and Head, ${ }^{3}$ Statistician, Dept. of Community Medicine, Bharati Vidyapeeth Deemed to be University \\ Medical College, Pune, Maharashtra, India
}

*Corresponding Author: Sudhanshu Ashok Mahajan

Email: sudhavaibhav1311@gmail.com

\begin{abstract}
Introduction: Hygiene refers to practices that help to maintain health and prevent the spread of diseases. School children are particularly vulnerable to neglect basic personal hygiene. Poor hygiene practices play major roles in increased burden of communicable dis eases in developing countries. This study was undertaken to assess the personal hygiene practices in school children living in slum area of Pune Materials and Methods: A cross-sectional study was conducted amongst 150 school children situated in a slum under the field practice area of urban health training center of a private medical college, Pune with the help of pre-designed, pre-tested structured questionnaire.

Results: The hygiene practices were graded as very poor, poor, average and good. It is observed that $8 \%$ had poor hygiene practices, $68 \%$ had average and $24 \%$ had good hygiene practices. Very poor hygiene practices were not seen.

Conclusion: There is need for parents and teachers as agents of health promotion to enshrine the values of personal hygiene in school children.
\end{abstract}

Keywords: Hygiene practices, school children, Pune.

\section{Introduction}

The term "hygiene" comes from the Greek word "Hygeia," which means goddess of health, cleanliness, and sanitation. ${ }^{1}$ Hygiene refers to practices associated with ensuring good health and cleanliness. ${ }^{2}$

Poor health hygiene practices can lead to communicable diseases basically within developing countries. Communicable diseases continue to be the major contributor to global morbidity and mortality. ${ }^{3}$ In Africa and Southeast Asia, $62 \%$ and $31 \%$ of all deaths are caused by infectious disease. ${ }^{4}$ Lack of proper hygiene and sanitation facilities increases burden of communicable diseases among developing countries. ${ }^{5}$ Children who learn what personal hygiene is and how to follow adequate hygiene practices will usually sustain those habits into their adulthood too.

Numerous studies have illuminated that effortless act of hand-washing and basic hygiene behaviour could prevent diarrhoea, acute respiratory infection and skin infections. ${ }^{6,7}$ Good personal hygiene has been found to be effective by reducing morbidity and mortality in children and now forms part of primary health prevention strategy.

Personal hygiene, which is also referred to as personal care, includes the following: bathing, hair, nail, foot, genital and dental cares, and washing of clothing among others. ${ }^{8}$ To our knowledge, limited data exist on this subject in developing countries like India and very few studies has been done in Maharashtra state. Hence the study has undertaken in school children living in urban slums of Pune with the following objectives:

1. To determine the socio demographic characteristics of urban slum school children.

2. To assess their personal hygiene habits.

3. To inspect their physical findings.

\section{Materials and Methods}

A cross sectional study was conducted from January 2019 to March 2019 in a school situated in a slum under the field practice area of urban health training center of a private medical college Pune. The population of Pune city is $3,124,458$ as per Census 2011. At present Pune municipal corporation has divided Pune in 14 wards covering 564 slums. The urban health training center gives health related services to sections of 3 wards. The services are given not only to slum dwellers but also to corporation and residential schools. A camp was organized in the urban health training center for the primary school children in grades I to $\mathrm{V}$, where the students came mainly from the neighboring slum locality. A pre designed, pretested questionnaire containing 30 questions was used to collect the data by interview technique after building a good repo with each student. The questionnaire consisted of A. socio-demographic Information e.g. age sex religion, education status of both mother and father B. Physical inspection of the students was performed on the basis of clean and tidy, average and dirty C. Personal hygiene habits of the student, in personal hygiene habits, 12 questions were asked. The habits of the students were divided into always, frequently, sometimes and occasionally.

A 4-point Linkert scale was included: very poor, poor, average and good to access the hygiene habits of school children.

At the end of the study, the parents were given information about their children's status of personal hygiene and related health condition and suggested to contact the urban health centre if needed. A brief health education session was also conducted for the class teachers, students and their parents after completion of the study. 


\section{Results}

Table 1: Distribution of the school children by socio-demographic characteristics

\begin{tabular}{|l|c|c|}
\hline Characteristics (n=150) & & \\
\hline Age (in years) & $11-13$ & $79(52.6)$ \\
\cline { 2 - 3 } & $14-16$ & $71(43.3)$ \\
\hline Gender & Male & $89(59.3)$ \\
\hline \multirow{4}{*}{ Eeligion } & Female & $61(40.6)$ \\
\hline & Hindu & $132(88)$ \\
\cline { 2 - 3 } & Muslim & $18(12)$ \\
\cline { 2 - 3 } & Illiterate & $21(14)$ \\
\cline { 2 - 3 } & Read and write & $22(14.6)$ \\
\cline { 2 - 3 } & Primary & $42(28)$ \\
\cline { 2 - 3 } & Middle & $4(2.6)$ \\
\cline { 2 - 3 } & Secondary & $42(28)$ \\
\cline { 2 - 3 } & More than SSC & $19(12.6)$ \\
\hline Education of mother & Illiterate & $21(14)$ \\
\cline { 2 - 3 } & Read and write & $18(12)$ \\
\cline { 2 - 3 } & Primary & $47(31.33)$ \\
\cline { 2 - 3 } & Middle & $2(1.33)$ \\
\cline { 2 - 3 } & Secondary & $45(30)$ \\
\cline { 2 - 3 } & More than SSC & $17(11.3)$ \\
\hline
\end{tabular}

This study shows the age of school children ranged from 11 to 16 years, maximum number of students (79) being between 11 to 13 years. Among the 150 students, 89 and 61 were male and female students respectively. Maximum students were Hindus $(88 \%)$ and rest of the students (12\%) were Muslims. Approximately equal number of Primary and Secondary school graduates' fathers were found in school children.

Table 2: Personal hygiene practices

\begin{tabular}{|l|c|c|c|c|}
\hline & Always & Frequently & Sometimes & Occasionally \\
\hline Wash hands before food & $63(42)$ & $61(40.6)$ & $15(10)$ & $11(7.33)$ \\
\hline Use soap to wash hands & $42(28)$ & $53(35.33)$ & $22(14.66)$ & $33(22)$ \\
\hline Alternatives to soap & $11(7.33)$ & $42(28)$ & $42(28)$ & $55(36.66)$ \\
\hline Wash hands after toilet & $80(53.33)$ & $59(39.33)$ & $5(3.33)$ & $6(4)$ \\
\hline Bath daily & $96(64)$ & $43(28.66)$ & $9(6)$ & $2(1.33)$ \\
\hline Wash hair & $130(86.66)$ & $3(2)$ & $17(11.33)$ & $0(0)$ \\
\hline Wear wash clothes & $33(22)$ & $66(44)$ & $45(30)$ & $6(4)$ \\
\hline Walk barefoot & $6(4)$ & $43(28.66)$ & $20(13.33)$ & $81(54)$ \\
\hline Wear clean socks daily & $30(20)$ & $42(28)$ & $55(36.66)$ & $23(15.33)$ \\
\hline Brush teeth twice daily & $36(24)$ & $25(16.66)$ & $20(13.33)$ & $69(46)$ \\
\hline Cut nails regularly & $0(0)$ & $5(3.33)$ & $97(64.66)$ & $48(32)$ \\
\hline Comb hair tidily & $96(64)$ & $50(33.33)$ & $3(2)$ & $1(0.66)$ \\
\hline
\end{tabular}

There have been 20 objects indicating the numerous kinds of hygiene habits. All the questions had been responded through selecting an appropriate option given under the questions. The table 2 is formulated per item of the questionnaire depicting the proportion of responses. In this table, $42 \%$ of the children said that they washed their hands always before taking meals while $40 \%$ washed frequently and nearly $28 \%$ students always used soap to wash their hands. Occasionally $36.6 \%$ students used alternatives to soap like ash, mud, grass etc to wash their hands. When the bathing schedule of the students analysed then it was found that only $64 \%$ always bath, $39.33 \%$ bathed frequently and only $1.33 \%$ bathed occasionally. The intervals by which the students always washed their hair was $86.66 \%$ followed by $11.33 \%$ sometimes in a month. $22 \%$ of the students always wear wash clothes. Surprisingly $24 \%$ of the students brushed their teeth twice in a day.

Table 3: Physical Inspection findings of the students

\begin{tabular}{|l|c|c|c|}
\hline Physical Inspection & Clean and Tidy & Average & Dirty \\
\hline Hair & $36(24)$ & $96(64)$ & $18(12)$ \\
\hline Nails and fingers & $20(13.3)$ & $44(29.3)$ & $86(57.3)$ \\
\hline
\end{tabular}




\begin{tabular}{|l|c|c|c|}
\hline Eyes & $47(31.3)$ & $60(40)$ & $43(28.6)$ \\
\hline Face & $46(30.6)$ & $57(38)$ & $47(31.3)$ \\
\hline Ears & $44(29.3)$ & $52(34.6)$ & $54(36)$ \\
\hline General Appearance & $47(31.3)$ & $69(46)$ & $34(22.6)$ \\
\hline
\end{tabular}

On physical inspection, it was found that $64 \%$ had clean and tidy hair whereas $12 \%$ of the students has dirty hairs. We found head lice, dandruff in the hair mostly in the female hair. Majority (57\%) had dirty untrimmed nails stuck with dirt under the nails

Table 4: Association of parent's education with hygiene practices

\begin{tabular}{|c|c|c|c|c|}
\hline Mother's education & $\begin{array}{l}\text { Adequate hygiene practice } \\
\text { (Always +Frequently } \\
\text { +Sometimes) }\end{array}$ & $\begin{array}{c}\text { Inadequate hygiene } \\
\text { practice } \\
\text { (Occasionally) }\end{array}$ & $\begin{array}{c}\text { Chi square } \\
\text { value }\end{array}$ & p value \\
\hline Illiterate, read \& write & 21 & 18 & \multirow[t]{3}{*}{12.82} & \multirow[t]{3}{*}{$<0.001$} \\
\hline Primary and middle & 42 & 07 & & \\
\hline Secondary \& >SSC & 54 & 08 & & \\
\hline \multicolumn{5}{|l|}{ Father's education } \\
\hline Illiterate, read \& write & 13 & 30 & \multirow[t]{3}{*}{12.76} & \multirow[t]{3}{*}{$<0.001$} \\
\hline Primary and middle & 17 & 29 & & \\
\hline Secondary \& >SSC & 38 & 23 & & \\
\hline \multicolumn{5}{|l|}{ Age } \\
\hline $11-13$ & 30 & 50 & \multirow[t]{2}{*}{10.83} & \multirow[t]{2}{*}{$<0.001$} \\
\hline $14-16$ & 51 & 19 & & \\
\hline \multicolumn{5}{|l|}{ Age } \\
\hline $11-13$ & 29 & 50 & \multirow[t]{2}{*}{0.7386} & \multirow[t]{2}{*}{$>0.001$} \\
\hline $14-16$ & 12 & 59 & & \\
\hline
\end{tabular}

Association of parent's education with hygiene practices like using of soap to wash hands and walk barefoot is shown in table 4. When statistical test was applied, significant association was found in using of soap to wash hands and walking barefoot with mothers and father education.

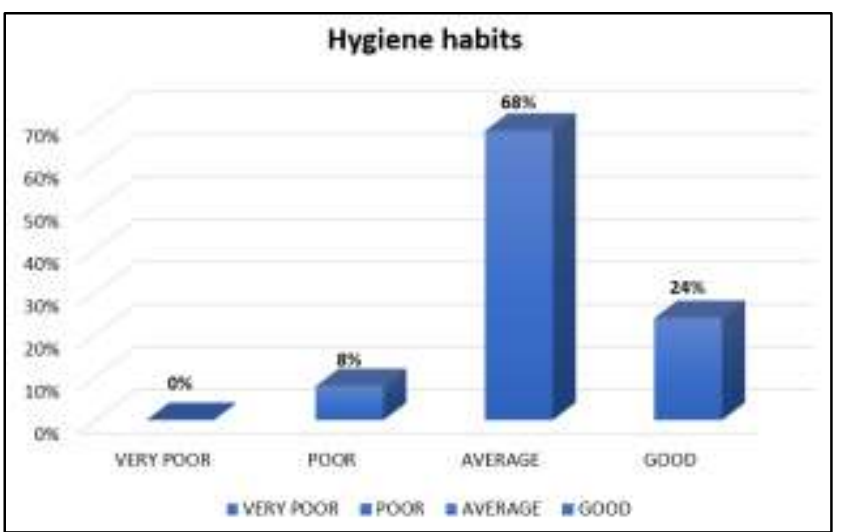

Fig 1: Distribution of school children according to their hygiene habits

As shown in Fig 1, among 150 students, 68\% had average hygiene habits followed by $24 \%$ had good hygiene habits.

that hygiene practices for all indicators of personal hygiene were not adequate among the study population.

Kunde Pallavi B, Adsul Balkrishnaet al, ${ }^{11}$ (2014) among school children in a Tribal area of Thane District, revealed

\section{Discussion}

Today's children will be tomorrow's adults. Good personal hygiene can boost child's self-esteem, as well as keep them healthy. Children are often considered as frontiers of the nation and still it is a vulnerable group of our society, since they are susceptible to various communicable diseases due to lack of hygiene which are responsible for most of the causes of sickness absenteeism in schools. Thus, we conducted a cross sectional study to assess the personal hygiene habits of school children in slum area.

This study showed that 59\% of children are males followed by $40 \%$ are females. The reasons for having less girl children are parental attitude, lack of security, socioeconomic conditions of parents and superstitions related to girls in India. India is one of the three countries in the world where Hinduism is the majority and the same is seen in our study that maximum number of students $(88 \%)$ belongs to Hindu religion. In line with previous research, M Sarkar ${ }^{9}$ also found that $73 \%$ students in slum area were Hindus.

We found maximum number of education of mother and father was upto primary level. The study conducted by Dr Suresh B Lal and Dr G Kavitha ${ }^{10}$ also revealed the same.

$64 \%$ of the children bath daily, $53 \%$ washed their hands after toilet, $42 \%$ used soap to wash their hands daily and $24 \%$ brush their teeth daily. These observations clearly indicate

that Uniform/clothes (53.9\%), Hair (14.18\%), Nail (53.9\%), and Hands \& feet $(26.95 \%)$ were in unfavourable condition, which was much higher among school children than present study. 
Statistically significant association was observed between the parent's education specially mother's education and adequate hygiene practices. Thus, mother's education play an important role in teaching the personal hygiene habits to their children. Therefore, schools should take part to conduct health education programmes for parents with a special emphasis on their role to improve the health habits of their children.

There was significant association also seen in adequate hygiene practice and age. Therefore, as the age increases there was significant improvement in the hygiene habits of the school children.

Thus, to conclude that that good hygiene practices were present in only $24 \%$. Parents education has significant influence on hygiene habits of children. Therefore improvement on the literacy status of the population should be focused on and there is significant increase in the personal hygiene practices with relation to age.

\section{Source of Funding}

None.

\section{Conflict of Interest}

None.

\section{References}

1. Al-Rifaai JM, Al Haddad AM, Qasem JA. Personal hygiene among college students in Kuwait: A Health promotion perspective. J Educ Health Promot. 2018;7:92.

2. Temitayo IO. Knowledge and practices of personal hygiene among senior secondary school students of ambassador's college, Ile-Ife, Nigeria. Texila Int J Public Health. 2016;4(4).
3. World Health Organization. Better Health for Poor Children. [Accessed August 4, 2009]. Available at: http://www.who.int/ child adolescent_health/documents/a91061/en/index.html

4. Curtis VA, Danquah LO, Aunger RV. Planned, motivated and habitual hygiene behaviour: An eleven country review. Health Educ Res. 2009;24:655-73.

5. Vivas AP, Gelaye B, Aboset N, Kumie A, Berhane Y, Williams MA. Knowledge, attitudes and practices (KAP) of hygiene among school children in Angolela, Ethiopia. J Prev Med Hyg. 2010;51(2):73-9.

6. Luby SP, Agboatwalla M, Feikin DR, Painter J, Billhimer Ward, Altaf Arshad. Effect of hand washing on child health: A randomized controlled trial. Lancet. 2005;366:225-33.

7. Shahid NS, Greenough WB, Samadi AR. Hand washing with soap reduces Diarrhoea and spread of bacterial pathogen in a Bangladesh village. J Diarrhoeal Dis Res. 1996; 14:85-9.

8. Ahmadu BU, Rimamchika M, Ibrahim A, Nnanubumom AA, Godiya A, Emmanuel P. State of personal hygiene among primary school children: A community based cohort study. Sudan J Paediatr. 2013;13(1):38-42.

9. Sarkar M. Personal hygiene among primary school children living in a slum of Kolkata, India. J Prev Med Hyg. 2013;54(3):153-8.

10. Lal BS, Kavitha G. Assessment of personal hygiene knowledge and practices: an empirical study of schooling children in Warangal. Int J Sci Res (IJSR). 2016;5(8):1521-4.

11. Chaudhari A, Mansuri S, Singh A, Talsania N. A study on Personal Hygiene of school going and non-school going children in Ahmedabad district, Gujarat. Natl J of Community Med. 2015;6(3):437-1.

How to cite this article: Mahajan SA, Gothankar JS, Deshmukh RB. Hygiene related practices amongst school children living in a slum of Pune. Indian J Forensic Community Med. 2020;7(1):38-41. 